\title{
Accelerated effect on Mitsunobu reaction via bis-N-tert-butoxycarbonylation protection of 2-amino-6-chloropurine and its application in a novel synthesis of penciclovir
}

\author{
Li-yan DAI ${ }^{\dagger}$, Qiu-long SHI, Jing ZHANG, Xiao-zhong WANG, Ying-qi CHEN \\ (Department of Chemical and Biological Engineering, Zhejiang University, Hangzhou 310027, China) \\ †E-mail: dailiyan@zju.edu.cn
}

Received July 10, 2013; Revision accepted Sept. 3, 2013; Crosschecked Sept. 12, 2013

\begin{abstract}
Solubility of 2-amino-6-chloropurine in Mitsunobu solvents could be significantly improved after its exocyclic amino group is protected via N-tert-butoxycarbonylation. The bis-Boc protected 2-amino-6-chloropurine also shows excellent activity and N9 selectivity in the coupling with various alcohols by a Mitsunobu reaction. Then, a new practical and efficient method is established for the synthesis of penciclovir (PCV) from bis-Boc-2-amino-6-chloropurine 9 and the side chain of 5-(2-hydroxyethyl)-2,2-dimethyl-1,3-dioxane 5-the latter being a more easily prepared cyclic precursor of the diacetate side chain used in the conventional process. The coupling of $\mathbf{9}$ with $\mathbf{5}$ proceeded regioselectively at a N9 position of purine derivative for a good yield under Mitsunobu conditions.
\end{abstract}

Key words: 2-amino-6-chloropurine, Mitsunobu reaction, bis-Boc protection, Penciclovir (PCV) doi: $10.1631 /$ jzus.A1300238

\section{Introduction}

Numerous nucleoside analogues in which the sugar residues have been replaced by acylic side-chains have been found to exhibit high antiviral activity (De Clercq, 1991). Purine derivatives (Fig. 1), in the majority N9 position, represent a plurality of important active substances endowed with antiviral activity. This group of compounds includes acyclovir (ACV) 1 (Schaeffer et al., 1978), ganciclovir (GCV) 2 (Ogilvie et al., 1982; Martin et al., 1983), penciclovir (PCV) 3 (Harnden et al., 1985; 1987; Harnden and Jarvest, 1987), and famciclovir (FCV) 4 (Green et al., 1992), and so on. Since Schaeffer et al. (1978) discovered that acyclovir is a promising anti-herpes virus agent, several groups have undertaken intensive

C Zhejiang University and Springer-Verlag Berlin Heidelberg 2013 studies to develop still more potent and effective acylic nucleoside analogues (Ashton et al., 1982; Smith et al., 1982; Martin et al., 1983). As a result, penciclovir (PCV) 3 and its pro-drug famciclovir (FCV) 4 were found to be potent and highly selective antiviral agents against both the herpes simplex virus (HSV) and the vari-cella-zoster virus (VZV) (Tippie et al., 1984). It was also reported that 3 exhibits anti hepatitis B virus (HBV) and duck hepatitis B virus (DHBV) activity (Korba and Boyd, 1996; Shaw et al., 1994).

To synthesize 3 and 4, 2-amino-6-chloropurine (ACP) is commonly used as a starting material, coupling with alkyl halide side chains (Geen et al., 1990; Geen et al., 1992; Kim et al., 1998; Brand et al., 1999; Toyokuni et al., 2003). However, considering its isomerization at $\mathrm{N} 7$ and $\mathrm{N} 9$ positions under acidic or alkaline conditions, the most challengeable issue is the selectivity of a N-alkylation at the N7 or N9 
position of ACP. Normally, alkylation takes place at the N9 position as well as at the N7 position of the purine moiety, and the N9/N7 ratio is usually less than 6:1 (Kim et al., 1998). Accordingly, to improve this ratio, several approaches have been reported, mainly involving changing the structure of the side chains (Geen et al., 1992) and modification of the ACP (Brand et al., 1999). For example, as reported by Zheng et al. (2004) (Fig. 2), a side chain 6 was synthesized and separated readily at $0{ }^{\circ} \mathrm{C}$. After coupling 6 with 2-amino-6-chloropurine 7, the ratio of the product 9-isomer purine (8a) and the 7-isomer purine (8b) could reach about 10:1. However, the reaction temperature must be strictly controlled as $\mathbf{6}$ decomposes easily even at room temperature and then an extra careful column chromatography separation procedure would be required to obtain pure 8a. Thus, finding a more practical and efficient method, which could avoid the formation of N7-alkylated compound and shorten the synthetic steps to obtain ACP, becomes attractive.

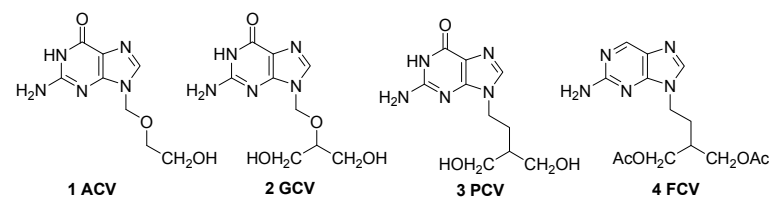

Fig. 1 Purine derivatives

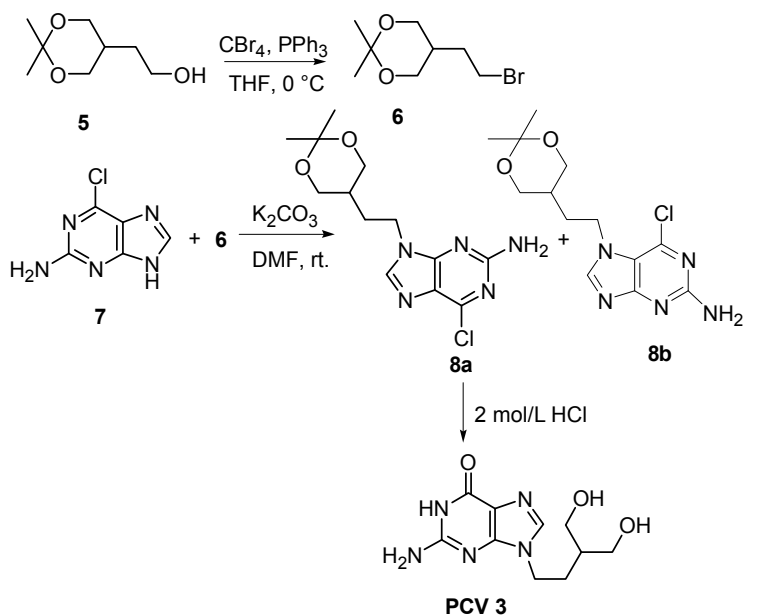

Fig. 2 Synthesis of penciclovir (PCV) with conventional method

The Mitsunobu reaction might be an alternative (potential) approach (Mitsunobu, 1981; Swamy et al., 2009). This reaction has become a very popular chemical transformation due to its mildness, occurring under essentially neutral conditions, and its stereospecificity, proceeding with complete Walden inversion of stereochemistry (Mitsunobu, 1981). Moreover, it permits C-O, C-S, C-N, or C-C bonds formed by the condensation of an acidic component with a primary or a secondary alcohol. Actually, some literature has already reported successful Mitsunobu coupling of ACP and adenine with allylic and benzylic alcohol, showing a good N9 selectivity (Yang et al., 2005; Kitade et al., 2006; Yin et al., 2006). However, a poor to modest yield $(20 \%-50 \%)$ and a limited substrate scope were observed. In order to improve these yields, Lu et al. (2007) developed a modified Mitsunobu method to couple purine with alcohols in a higher temperature $\left(70^{\circ} \mathrm{C}\right)$, along with two rounds of the Mitsunobu reaction; yet its long reaction procedure and poor atom economy weaken its potential. The poor solubility of ACP or its derivatives in THF, the preferred solvent for Mitsunobu reactions, is likely the primary reason for these defects being observed.

A possible process to improve the solubility of $\mathrm{ACP}$ is to make use of the tert-butoxycarbonyl group (Boc), which can serve as the protection of the exocylic amino groups functionality and increase the lipophilicity of the base portion of the purine. Another advantage of the Boc protection group is that its acidolytic removal is less sensitive to steric factors and can also be removed under neutral conditions (Hwu et al., 1996; Siro et al., 1998). In contrast, a few studies have recently been reported that apply the Boc group in the protection of nucleobase (Sikchi and Hultin, 2006; Porcheddu et al., 2008). As described by Porcheddu et al. (2008), solubility of nucleobases, including guanine, was increased in some organic solvents after protected by Boc groups. In addition, some results in our previous study (Yang et al., 2011) demonstrated a very good improvement in coupling purine derivatives under Mitsunobu conditions. Thus, it could be safer to presume that protecting amino groups of ACP with Boc would be an ideal way for its application in the synthesis of PCV 3 and offer similar results as shown under Mitsunobu conditions.

In this study, we firstly synthesized a bis-Boc protected ACP, namely, bis-Boc-2-amino-6chloropurine 9 (Fig. 3) and investigated its solubility in several different Mitsunobu solvents, then coupling 
bis-Boc-2-amino-6-chloropurine 9 with a large scope of alcohols confirmed its good reactivity for a Mitsunobu reaction and successfully developed a new and efficient method for the preparation of PCV using Mitsunobu coupling reaction as the key step.

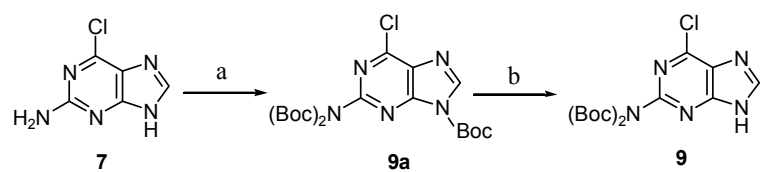

Fig. 3 Synthesis of bis-Boc-6-chloropurine 9 a: 2-amino-6-chloropurine, 4,4-dimethylaminopyridine (DMAP), THF and $\mathrm{Boc}_{2} \mathrm{O}, 25^{\circ} \mathrm{C}, \mathrm{N}_{2} ;$ b: $\mathrm{MeOH}, \mathrm{NaHCO}_{3}, 55^{\circ} \mathrm{C}$

\section{Experimental}

\subsection{General}

Acetic ether and hexane, used for extraction and chromatography, were distilled. Absolute anhydrous THF used in the Mitsunobu reactions were prepared by distillation over a drying agent ( $\mathrm{Na}$ /benzophenone). All other reagents were purchased and used without further purification. Thin-layer chromatography (TLC) analyses were conducted on the Merck Kieselgel 60 F254 plates. Flash chromatography was performed using a silica gel Merck 60 (particle size 0.040-0.063 mm). All ${ }^{1} \mathrm{H}$ NMR and ${ }^{13} \mathrm{C}$ NMR spectra were recorded on the BRUKER AVANCE DX500 (BRUKER AVANCE, Germany), using $\mathrm{CDCl}_{3}$ or d6-DMSO as solvent at room temperature. Chemical shifts are given in $10^{-6}$ relative to tetramethylsilane (TMS) and the coupling constants $J$ are given in $\mathrm{Hz}$. TMS served as an internal standard $(\delta=0)$ for ${ }^{1} \mathrm{H}$ NMR, and $\mathrm{CDCl}_{3}$ was used as an internal standard $\left(\delta=77.0 \times 10^{-6}\right)$ for ${ }^{13} \mathrm{C}$ NMR. Melting points $(\mathrm{mp})$ were obtained on a Melting Point WRR (Shanghai Precision \& Scientific Instrument Co., Ltd., China).

\subsection{Bis-Boc-2-amino-6-chloropurine (9)}

1. $t$-Butyl-2-[bis(t-butoxycarbonyl)amino]-6chloro-9H-purine-9-carboxylate (9a)

To a $250 \mathrm{ml} \mathrm{N} \mathrm{N}_{2}$-flushed flask with dry THF $(100 \mathrm{ml})$, equipped with a magnetic stir bar, 2-amino-6-chloropurine $(2.0 \mathrm{~g}, 11.8 \mathrm{mmol})$ and DMAP $(0.14 \mathrm{~g}, 1.18 \mathrm{mmol})$ were added. $\mathrm{Boc}_{2} \mathrm{O}$ (10.3 g, $47.2 \mathrm{mmol})$ was added to the stirred suspension under an $\mathrm{N}_{2}$ atmosphere, then the reaction mix- ture was stirred for $6 \mathrm{~h}$ at room temperature (TLC analysis indicated the disappearance of 2-mino-6chloropurine). The excess amount of THF was removed, and the crude product was dissolved in AcOEt $(400 \mathrm{ml})$, washed with $\mathrm{HCl}$ aqueous $(2 \mathrm{~mol} / \mathrm{L}$, $1 \times 30 \mathrm{ml})$ and brine $(2 \times 50 \mathrm{ml})$, dried with $\mathrm{Na}_{2} \mathrm{SO}_{4}$ and concentrated in vacuo to give a white solid $(5.2 \mathrm{~g}$, 94.5\%). mp 51-52 ${ }^{\circ} \mathrm{C} ;{ }^{1} \mathrm{H}$ NMR (500 $\left.\mathrm{MHz}, \mathrm{CDCl}_{3}\right)$ : $\delta=1.47\left(\mathrm{~s}, 18 \mathrm{H}, \mathrm{C}\left(\mathrm{CH}_{3}\right)_{3}\right), 1.69\left(\mathrm{~s}, 9 \mathrm{H}, \mathrm{C}\left(\mathrm{CH}_{3}\right)_{3}\right), 8.58$ (s, $1 \mathrm{H}, \mathrm{CH}) ;{ }^{13} \mathrm{C}$ NMR $\left(125 \mathrm{MHz}, \mathrm{CDCl}_{3}\right) \delta=153.8$, $152.0,151.8,150.6,145.5,144.7,130.8,88.0,83.9$, 28.0 .

2. Bis-Boc-2-amino-6-chloropurine (9)

A solution of the white solid obtained above $(14 \mathrm{~g}, 30 \mathrm{mmol})$ in $\mathrm{MeOH}(400 \mathrm{ml})$ was added to saturated $\mathrm{NaHCO}_{3}$ aqueous $(200 \mathrm{ml})$, then the turbid solution was stirred at $55{ }^{\circ} \mathrm{C}$ for $2 \mathrm{~h}$, at which point clean conversion to bis-Boc protected adenine was observed by TLC. After evaporation of $\mathrm{MeOH}$, the residue mixture was cooled, added $5 \mathrm{~mol} / \mathrm{L}$ hydrochloric acid to get $\mathrm{pH}=7$ (approximate). A large amount of white solid formed, the reaction mixture was filtrated and then dried under a vacuum to give a white solid $9(10.5 \mathrm{~g}, 95.5 \%)$. mp $101.3-103.3{ }^{\circ} \mathrm{C} ;{ }^{1} \mathrm{H}$ NMR $\left(500 \mathrm{MHz}, \mathrm{CDCl}_{3}\right): \delta=1.50\left(\mathrm{~s}, 18 \mathrm{H}, \mathrm{C}\left(\mathrm{CH}_{3}\right)_{3}\right)$, $8.41(\mathrm{~s}, 1 \mathrm{H}, \mathrm{CH}) ;{ }^{13} \mathrm{C}$ NMR $\left(125 \mathrm{MHz}, \mathrm{CDCl}_{3}\right)$ $\delta=153.5,151.9,151.6,151.3,145.6,128.5,82.7,28.5$.

\subsection{5-(2-hydroxyethyl)-2,2-dimethyl-1,3-dioxane} (5)

2-hydroxymethyl-1,4-butanediol $\mathbf{1 1}$ (8.10 g, $67.4 \mathrm{mmol})$ and 2,2-dimethoxypropane $(13 \mathrm{ml}$, $105.7 \mathrm{mmol})$ were dissolved in dry THF $(20 \mathrm{ml})$. The mixture was stirred and $p$-toluenesulfonic acid monohydrate $(0.64 \mathrm{~g}, 3.4 \mathrm{mmol})$ was added, the clear solution was stirred at room temperature for $12 \mathrm{~h}$, triethylamine $(10 \mathrm{ml})$ was added to quench the reaction, and the solution was stirred for $30 \mathrm{~min}$. Then solvents were removed to leave a colorless liquid, the residue was subject to column chromatography on silica gel eluted with 2:1 EtOAc/hexane to give a colorless liquid 5 (6.2 g, 61.5\%), $R_{\mathrm{f}}=0.46 \quad(2: 1$ EtOAc/hexane). ${ }^{1} \mathrm{H}$ NMR (500 MHz, $\left.\mathrm{CDCl}_{3}\right): \delta=3.99$ (dd, $2 \mathrm{H}$, Heq. $\left.J_{1}=11.80 \mathrm{~Hz}, J_{2}=4.45 \mathrm{~Hz}, \mathrm{CH}_{2}\right) ; 3.80(\mathrm{t}$, $\left.2 \mathrm{H}, J=6.71 \mathrm{~Hz}, \mathrm{CH}_{2}\right), 3.34$ (dd, $2 \mathrm{H}, \mathrm{Hax} . J_{1}=11.80 \mathrm{~Hz}$, $\left.J_{2}=8.11 \mathrm{~Hz}, \mathrm{CH}_{2}\right), 1.90-1.98(\mathrm{~m}, 2 \mathrm{H}, \mathrm{CH}$ and $\mathrm{OH})$, $1.62\left(\mathrm{q}, 2 \mathrm{H}, J=6.85 \mathrm{~Hz}, \mathrm{CH}_{2}\right) ;{ }^{13} \mathrm{C}$ NMR $(125 \mathrm{MHz}$, $\left.\mathrm{CDCl}_{3}\right): \delta=100.5,69.8,60.4,31.9,30.3,21.2$. 


\subsection{Bis-Boc-2-amino-6-chloro-9-[2-(2,2-dimethyl- 1,3-dioxan-5-yl)ethyl] purine (12)}

Bis-Boc-2-amino-6-chloropurine 9 (1.0 equivalent) was added to a solution of the side chain 5 (1.1 equivalent) and phosphine reagent (1.1 equivalent) in anhydrous THF under $\mathrm{N}_{2}$ atmosphere at $0{ }^{\circ} \mathrm{C}$, the resulting solution was treated with di- $p$-nitrobenzyl azocarboxylate (DNAD) (1.1 equivalent) dropwise and the reaction mixture was continued at room temperature for $8 \mathrm{~h}$, then the solvent was evaporated and the residue dissolved in cyclohexane. The triphenylphosphane oxide precipitated and was filtered off and then the filtrate evaporated under reduced pressure. The product was purified by a column chromatography on silica gel to obtain the pure products as a white solid. $\mathrm{mp}>280{ }^{\circ} \mathrm{C}(\mathrm{dec}) ;{ }^{1} \mathrm{H}$ NMR $\left(500 \mathrm{MHz}, \mathrm{CDCl}_{3}\right): \delta=8.36(\mathrm{~s}, 1 \mathrm{H}, \mathrm{CH}), 4.02(\mathrm{t}, 2 \mathrm{H}$, $J=7.23 \mathrm{~Hz}, \mathrm{CH}_{2}$ ), 3.79 (dd, 2H, Heq. $J_{1}=11.57 \mathrm{~Hz}$, $\left.J_{2}=4.46 \mathrm{~Hz}, \mathrm{CH}_{2}\right), 3.56\left(\mathrm{dd}, 2 \mathrm{H}\right.$, Hax. $J_{1}=11.57 \mathrm{~Hz}$, $\left.J_{2}=8.77 \mathrm{~Hz}, \mathrm{CH}_{2}\right), 1.67$ (q, 2H, $\left.J=7.22 \mathrm{~Hz}, \mathrm{CH}_{2}\right), 1.53$ $-1.61(\mathrm{~m}, 1 \mathrm{H}, \mathrm{CH}), 1.47\left(\mathrm{~s}, 18 \mathrm{H}, \mathrm{C}\left(\mathrm{CH}_{3}\right)_{3}\right), 1.39$ (s, $\left.3 \mathrm{H}, \mathrm{CH}_{3}\right), 1.36\left(\mathrm{~s}, 3 \mathrm{H}, \mathrm{CH}_{3}\right) ;{ }^{13} \mathrm{C} \mathrm{NMR}(125 \mathrm{MHz}$, $\left.\mathrm{CDCl}_{3}\right): \delta=154.3,151.7,151.5,151.1,128.0,104.8$, $81.7,71.5,50.8,33.7,28.6,26.2,25.7$.

\subsection{2-amino-6-chloro-9-[2-(2,2-dimethyl-1,3- dioxan-5-yl) ethyl]purine (8a)}

A mixture of compound 12 (2.56 g, $5.0 \mathrm{mmol})$, 2,6-dimethyl pyridine $(1.18 \mathrm{ml}, 10 \mathrm{mmol})$ and dry DCM $(20 \mathrm{ml})$ was stirred at $0{ }^{\circ} \mathrm{C}$, then TBTMS-OTf was added dropwise; after the addition, the reaction mixture was stirred at room temperature until TLC showed that compound $\mathbf{1 2}$ had completely disappeared. Then $30 \mathrm{ml}$ saturated ammonium chloride solution was added, separated the organic layer, extracted with DCM $(2 \times 20 \mathrm{ml})$, combined and washed by saturated $\mathrm{NaCl}(2 \times 40 \mathrm{ml})$, dried with anhydrous sodium sulfate and evaporated to give a white solid (1.21 g, 78\%). mp 125-126 ${ }^{\circ} \mathrm{C} ;{ }^{1} \mathrm{H}$ NMR (500 MHz, $\left.\mathrm{CDCl}_{3}\right): \delta=8.07(\mathrm{~s}, 1 \mathrm{H}, \mathrm{CH}), 6.99\left(\mathrm{~s}, 2 \mathrm{H}, \mathrm{NH}_{2}\right), 4.12$ $\left(\mathrm{t}, 2 \mathrm{H}, J=7.31 \mathrm{~Hz}, \mathrm{CH}_{2}\right), 3.82\left(\mathrm{dd}, 2 \mathrm{H}, 4^{\prime}-\mathrm{Heq}, J_{1}=\right.$ $\left.11.79 \mathrm{~Hz}, J_{2}=4.50 \mathrm{~Hz}, \mathrm{CH}_{2}\right), 3.53\left(\mathrm{dd}, 2 \mathrm{H}, 4^{\prime}-\mathrm{Hax}, J_{1}\right.$ $\left.=11.79 \mathrm{~Hz}, J_{2}=8.80 \mathrm{~Hz}, \mathrm{CH}_{2}\right), 1.74(\mathrm{q}, 2 \mathrm{H}, J=7.30 \mathrm{~Hz}$, $\left.\mathrm{CH}_{2}\right), 1.53-1.65(\mathrm{~m}, 1 \mathrm{H}, \mathrm{CH}), 1.36\left(\mathrm{~s}, 3 \mathrm{H}, \mathrm{CH}_{3}\right), 1.31$ (s, $\left.3 \mathrm{H}, \mathrm{CH}_{3}\right) ;{ }^{13} \mathrm{C} \mathrm{NMR}\left(125 \mathrm{MHz}, \mathrm{CDCl}_{3}\right): \delta=159.94$, 150.31, 150.26, 141.84, 132.11, 100.52, 68.14, 52.90, $31.32,26.84,26.05$.

\subsection{9-[4-hydroxy-3-(hydroxymethyl)butyl] gua- nine (PCV 3)}

Compound 12 (5.12 g, $10 \mathrm{mmol}$ ) was dissolved in THF $(20 \mathrm{ml})$ hydrochloric acid $(2 \mathrm{~mol} / \mathrm{L}, 20 \mathrm{ml})$. The mixture was stirred for $2 \mathrm{~h}$ at $70{ }^{\circ} \mathrm{C}$, and then slowly warmed to reflux for $2 \mathrm{~h}$. After evaporation of the THF under reduced vacuum, $10 \%$ aqueous $\mathrm{NaOH}$ solution was added to neutralize the residual liquid, and a large amount of off-white solid formed, filtered, washed with acetone and then water, and dried under vacuum to give an off-white solid 3 (2.07 g, 82\%). mp 274.6-276.9 ${ }^{\circ} \mathrm{C}$.

\section{Results and discussion}

To begin with, bis-Boc-2-amino-6-chloropurine 9 was synthesized from 2-amino-6-chloropurine 7 in high yield followed by Subhakar's procedure (Dey and Garner, 2000). The solubility of bis-Boc2-amino-6-chloropurine 9 was investigated and the results are shown in Table 1. Unlike 2-amino6-chloropurine 7, known for its notorious insolubility in most common solvents, the solubility of 9 in DCM, methylbenzene, acetonitrile, and especially in THF was increased dramatically.

Table 1 Mole fraction solubility $x$ of bis-Boc-2-amino-6chloropurine 9 in different Mitsunobu solvents

\begin{tabular}{ccccc}
\hline$T(\mathrm{~K})$ & \multicolumn{4}{c}{${\text { Solubility } x^{\mathrm{a}}(\%)}^{\mathrm{a}}( \pm 0.05 \mathrm{~K})$} \\
\cline { 2 - 5 } & $\mathrm{THF}^{\mathrm{b}}$ & $\mathrm{DCM}^{\mathrm{b}}$ & Methylbenzene $^{\mathrm{b}}$ & Acetonitrile $^{\mathrm{b}}$ \\
\hline 273.15 & 0.1141 & 0.0493 & 0.0213 & 0.0150 \\
278.15 & 0.1191 & 0.0552 & 0.0253 & 0.0178 \\
283.15 & 0.1251 & 0.0613 & 0.0303 & 0.0210 \\
288.15 & 0.1299 & 0.0664 & 0.0349 & 0.0244 \\
293.15 & 0.1352 & 0.0734 & 0.0405 & 0.0288 \\
298.15 & 0.1399 & 0.0809 & 0.0470 & 0.0347 \\
303.15 & 0.1463 & 0.0894 & 0.0544 & 0.0417 \\
308.15 & 0.1523 & 0.0983 & 0.0634 & 0.0501 \\
313.15 & 0.1581 & 0.1081 & 0.0734 & 0.0617 \\
\hline
\end{tabular}

a: the solubility of bis-Boc-2-amino-6-chloropurine 9 was measured by our previous method with temperature ranging from $273.15 \mathrm{~K}$ to $313.15 \mathrm{~K}$ (Wang et al., 2008) at atmospheric pressure. The laser monitoring observation technique was used to determine the disappearance of the solid phase in a solid and liquid mixture. b: all the solvents were further purified by distillation in dry agent ( $\mathrm{Na}$ /benzophenone) and the sample bis-boc-2-amino-6-chloropurine 9 was dried in vacuum for over $2 \mathrm{~d}$

As shown in Table 1, THF, which is the most common solvent in Mitsunobu reaction, has great 
solubility for bis-Boc-2-amino-6-chloropurine 9 . Afterwards, the best solvent THF was taken for coupling 9 with a number of alcohols under normal Mitsunobu conditions to investigate its reactivity. The results were illustrated in Table 2 . We clearly learned that bis-Boc-2-amino-6-chloropurine 9, as an excellent nucleophilic precursor, was able to react with a large number of alcohols, including primary alcohol, secondary alcohol, allyl alcohol, benzyl alcohol, etc., with high N9 selectivity and yields. Moreover, tert-Butyl alcohol still could not react with a protected purine as in the previous study (Yang et al., 2011), owing to its steric hindrance in tertiary carbon.

According to the research results above, it is more reasonable and assuring to prepare $\mathrm{PCV}$ via a Mitsunobu reaction. This novel method for the preparation of PCV is indicated in Fig. 4. First, the side chain of 5-(2-hydroxyethyl)-2,2-dimethyl-1,3 -dioxane 5 was achieved through the commercially available starting material 2-hydroxymethyl-1,4butanediol 11 reacting with 2,2-dimethoxypropane catalyzed by $p$-toluenesulfonic acid. The free $-\mathrm{OH}$ group of compound $\mathbf{5}$ is not necessary to be converted to the other leaving group such as chlorine, tosylate or methanesulphonate, which is always taken as a necessary step in the previous method or many other previous studies for the preparation of PVC till now (Harnden and Jarvest, 1985; Harnden et al., 1987; Zheng et al., 2004), making the synthesis of the side chain part of our method much more convenient and practical.

Our next objective was the synthesis of PCV. As was expected, bis-Boc-2-amino-6-chloropurine 9 combined with the side chain $\mathbf{5}$ (1.1 equivalent) under normal Mitsunobu conditions successfully obtained the desired N9-alkylated compound $\mathbf{1 2}$ in 92\% yield without the undesired $\mathrm{N} 7$ alkylation by-product being formed. Importantly, the reaction conditions were significantly milder than those reported in recent studies (Geen et al., 1990; 1992; Kim et al., 1998; Brand et al., 1999; Toyokuni et al., 2003), requiring only 1.1 equivalent of each of the alcohol, $\mathrm{PPh}_{3}$ and DNAD, and proceeding to completion within $60 \mathrm{~min}$ at room temperature. This is mainly due to the enhanced solubility of the compound 9 as mentioned above. By process $\mathrm{c}$ in Fig. 4, compound 8a was obtained under neutral conditions. It is ${ }^{1} \mathrm{H}$ and ${ }^{13} \mathrm{C}$ NMR spectra further indicated that no 7-isomer purine (8b) was formed. Subsequently, we could obtain PCV 3 in an acid condition as procedure e; or directly starting from 12, where hydrolytic dechlorination and deprotection step(s) were accomplished in one pot under mild acid conditions $(2 \mathrm{~mol} / \mathrm{L}$, hydrochloric acid in THF at room temperature) to afford the target PCV 3 in $80 \%-85 \%$ yield (process d). The overall yield of PCV from 11 was $44.5 \%$ higher than that in previous study (16\%) (Zheng et al., 2004).

Table 2 Investigation of the reactivity of bis-Boc-2amino-6-chloropurine 9 with different alcohols

\begin{tabular}{|c|c|c|c|}
\hline Entry & Alcohol & Product & Isolated yield (\%) \\
\hline 1 & $\mathrm{DH}$ & 10a & 90.2 \\
\hline 2 & $\mathrm{OH}$ & $10 \mathrm{~b}$ & 86.6 \\
\hline 3 & & $10 \mathrm{c}$ & 83.3 \\
\hline 4 & & 10d & 84.8 \\
\hline 5 & & $10 \mathrm{e}$ & 86.4 \\
\hline 6 & & $10 f$ & 81.2 \\
\hline 7 & & $10 \mathrm{~g}$ & 81.5 \\
\hline 8 & & $10 \mathrm{~h}$ & 80.7 \\
\hline 9 & & $10 \mathrm{i}$ & 0 \\
\hline
\end{tabular}

a): a mixture of 9 (1.0 equivalent), alcohol (1.1 equivalent) and phosphine reagent (1.1 equivalent) in anhydrous THF stirring under $\mathrm{N}_{2}$ atmosphere at $0{ }^{\circ} \mathrm{C}$, then treated with azo-reagent DNAD (1.1 equivalent) warmed to room temperature; $b$ ): the mixture of the products from procedure a, THF $(20 \mathrm{ml})$ and aqueous hydrochloric acid $(2 \mathrm{~mol} / \mathrm{L}, 20 \mathrm{ml})$ was refluxed for $2 \mathrm{~h}$ at $70{ }^{\circ} \mathrm{C}$
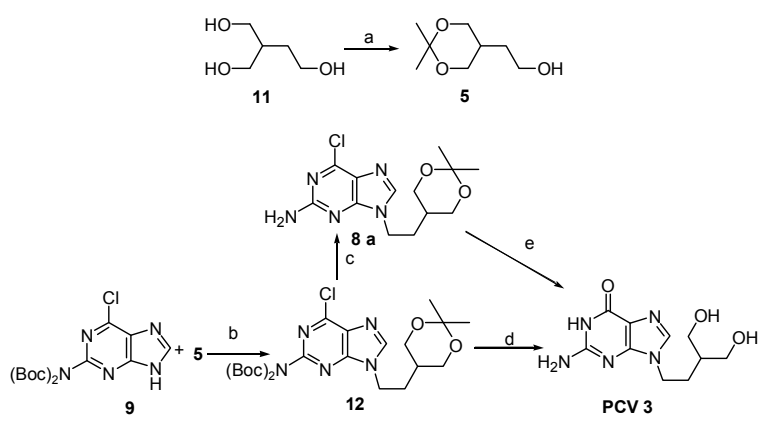

Fig. 4 Synthesis of penciclovir (PCV) with new method a: 2,2-dimethoxypropane, $p$-toluenesulfonic acid, THF; b: 1.1 equivalent of the side chain 5, 1.1 equivalent of $\mathrm{PPh}_{3}$, and 1.1 equivalent of azodicarboxylate reagent at rt. in THF; c: TBDMS-OTf, DCM; d: aqueous hydrochloric acid ( $2 \mathrm{~mol} / \mathrm{L})$, THF; e: aqueous hydrochloric acid $(2 \mathrm{~mol} / \mathrm{L})$ 


\section{Conclusions}

In this study, ACP was protected with a bis-Boc carbamate group and showed a significant increase of solubility in the favorite Mitsunobu solvents. Coupling bis-Boc-2-amino-6-chloropurine 9 with different alcohols indicated a higher N9 selectivity and good reactivity in a Mitsunobu reaction. The results provided a convenient and practical protocol to prepare PCV from ACP, avoiding the presence of undesired N7 by-product and requiring only a few synthetic steps with higher yields.

\section{Acknowledgements}

We are grateful to Prof. Jun-quan SUN of Department of the Chemical and Biological Engineering of Zhejiang University, China for his insightful advice into our research work. We also would like to express our appreciation to Dr. Shi-chao YU and others for language polishing.

\section{References}

Ashton, W.T., Karkas, J.D., Field, A.K., Tolman, R.L., 1982. Activation by thymidine kinase and potent antiherpetic activity of 2'-nor-2'-deoxyguanosine (2'NDG). Biochemical and Biophysical Research Communications, 108(4):1716-1721. [doi:10.1016/S0006-291X(82)80109-5]

Brand, B., Reese, C.B., Song, Q., Visintin, C., 1999. Convenient syntheses of 9-[4-hydroxy-3-(hydroxymethyl)butyl] guanine (penciclovir) and 9-[4-acetoxy-3-(acetoxymethyl) butyl]-2-amino-9H-purine (famciclovir). Tetrahedron, 55(16):5239-5252. [doi:10.1016/S0040-4020(99)00169-6]

De Clercq, E., 1991. Broad-spectrum anti-DNA virus and antiretrovirus activity of phosphonylmethoxyalkylpurines and pyrimidines. Biochemical Pharmacology, 42(5):963-972. [doi:10.1016/0006-2952(91)90276-B]

Dey, S., Garner, P., 2000. Synthesis of tert-butoxycarbonyl (Boc)-protected purines. The Journal of Organic Chemistry, 65(22):7697-7699. [doi:10.1021/jo000983i]

Geen, G.R., Grinter, T.J., Kincey, P.M., Jarvest, R.L., 1990. The effect of the C-6 substituent on the regioselectivity of $\mathrm{N}$-alkylation of 2-aminopurines. Tetrahedron, 46(19): 6903-6914. [doi:10.1016/S0040-4020(01)87878-9]

Geen, G.R., Kincey, P.M., Choudary, B.M., 1992. Regiospecific Michael additions with 2-aminopurines. Tetrahedron Letters, 33(32):4609-4612. [doi:10.1016/S0040-4039(00) 61326-6]

Harnden, M.R., Jarvest, R.L., 1985. An improved synthesis of the antiviral acyclonucleoside 9-(4-hydroxy-3-hydroxymethylbut-1-yl) guanine. Tetrahedron Letters, 26(35): 4265-4268. [doi:10.1016/S0040-4039(00)99010-5]
Harnden, M.R., Jarvest, R.L., Bacon, T.H., Boyd, M.R., 1987. Synthesis and antiviral activity of 9-[4-hydroxy-3(hydroxymethyl) but-1-yl] purines. Journal of Medicinal Chemistry, 30(9):1636-1642. [doi:10.1021/jm00392a020]

Hwu, J.R., Jain, M.L., Tsay, S.C., Hakimelahi, G.H., 1996. Ceric ammonium nitrate in the deprotection of tertbutoxycarbonyl group. Tetrahedron Letters, 37(12):20352038. [doi:10.1016/0040-4039(96)00211-0]

Kim, D.K., Lee, N., Kim, Y.W., Chang, K.Y., Kim, J.S., Im, G.J., Choi, W.S., Jung, I.H., Kim, T.S., Hwang, Y.Y., 1998. Synthesis and evaluation of 2-amino-9-(3-hydroxymethyl4-alkoxycarbonylo-xybut-1-yl) purines as potential prodrugs of penciclovir. Journal of Medicinal Chemistry, 41(18):3435-3441. [doi:10.1021/jm980138g]

Kitade, Y., Ando, T., Yamaguchi, T., Hori, A., Nakanishi, M., Ueno, Y., 2006. 4'-fluorinated carbocyclic nucleosides: synthesis and inhibitory activity against $S$-adenosyl-1homocysteine hydrolase. Bioorganic \& Medicinal Chemistry, 14(16):5578-5583. [doi:10.1016/j.bmc.2006.04.023]

Korba, B.E., Boyd, M.R., 1996. Penciclovir is a selective inhibitor of hepatitis B virus replication in cultured human hepatoblastoma cells. Antimicrobial Agents and Chemotherapy, 40(13):1282-1284.

Lu, W., Sengupta, S., Petersen, J.L., Akhmedov, N.G., Shi, X., 2007. Mitsunobu coupling of nucleobases and alcohols: an efficient, practical synthesis for novel nonsugar carbon nucleosides. Journal of Organic Chemistry, 72(13):50125015. [doi:10.1021/jo070515+]

Martin, J.C., Dvorak, C.A., Smee, D.F., Matthews, T.R., Verheyden, J.P.H., 1983. 9-(1,3-dihydroxy-2-propoxymethyl) guanine: a new potent and selective antiherpes agent. Journal of Medicinal Chemistry, 26(5):759-761. [doi:10. 1021/jm00359a023]

Mitsunobu, O., 1981. The use of diethyl azodicarboxylate and triphenylphosphine in synthesis and transformation of natural products. Synthesis, 1981(1):1-28. [doi:10.1055/ s-1981-29317]

Ogilvie, K.K., Cheriyan, U.O., Radatus, B.K., Smith, K.O., Galloway, K.S., Kennell, W.L., 1982. Biologically active acyclonucleoside analogues. II. The synthesis of 9-[[2hydroxy-1-(hydroxymethyl)ethoxy]methyl] guanine (BIOLF-62). Canadian Journal of Chemistry, 60(24): 3005-3010. [doi:10.1139/v82-430]

Porcheddu, A., Giacomelli, G., Piredda, I., Carta, M., Nieddu, G., 2008. A Practical and efficient approach to PNA monomers compatible with Fmoc-mediated solid-phase synthesis protocols. European Journal of Organic Chemistry, 2008(34):5786-5797. [doi:10.1002/ejoc.200800 891]

Schaeffer, H.J., Beauchamp, L., Miranda, P.D., Elion, G.B., Bauer, D.J., Collins, P., 1978. 9-(2-hydroxyethoxymethyl) guanine activity against viruses of the herpes group. $\mathrm{Na}$ ture, 272(5654):583-585. [doi:10.1038/272583a0]

Shaw, T., Amor, P., Civitico, G., Boyd, M., Locarnini, S., 1994. In vitro antiviral activity of penciclovir, a novel purine nucleoside, against duck hepatitis B virus. Antimicrobial Agents and Chemotherapy, 38(4):719-723. [doi:10.1128/ AAC.38.4.719] 
Smith, K.O., Galloway, K.S., Kennell, W.L., Ogilvie, K.K., Radatus, B.K., 1982. A new nucleoside analog, 9-[[2hydroxy-1-(hydroxymethyl)ethoxyl]methyl] guanine, highly active in vitro against herpes simplex virus types 1 and 2. Antimicrobial Agents and Chemotherapy, 22(1): 55-61. [doi:10.1128/AAC.22.1.55]

Tippie, M.A., Martin, J.C., Smee, D.F., Matthews, T.R., Verheyden, J.P.M., 1984. Antiherpes simplex virus activity of 9-[4-hydroxy-3-(hydroxymethyl)-1-butyl] guanine. $\mathrm{Nu}$ cleosides and Nucleotides, 3(5):525-535. [doi:10.1080/ 07328318408081287]

Toyokuni, T., Walsh, J.C., Namavari, M., Shinde, S.S., Moore, J.R., Barrio, J.R., Satyamurthy, N., 2003. Selective and practical synthesis of penciclovir. Synthetic Communications, 33(22):3897-3905. [doi:10.1081/SCC-120026312]

Sikchi, S.A., Hultin, P.G., 2006. Solventless protocol for efficient Bis-N-Boc protection of adenosine, cytidine, and guanosine derivatives. Journal of Organic Chemistry, 71(16):5888-5891. [doi:10.1021/jo060430t]

Siro, J.G., Martin, J., Garcia-Navio, J.L., Remuinan, M.J., Vaquero, J.J., 1998. Easy microwave assisted deprotection of N-Boc derivatives. Synlett, 1998(2):147-148. [doi:10. 1055/s-1998-1604]

Swamy, K.C.K., Kumar, N.N.B., Balaraman, E., Kumar, K.V.P.P., 2009. Mitsunobu and related reactions: advances and applications. Chemical Reviews, 109(6):2551-2651. [doi:10.1021/cr800278z]

Wang, L., Dai, L.Y., Lei, M., Chen, Y., 2008. Solubility of hexamethylenetetramine in a pure water, methanol, acetic acid, and ethanol+water mixture from (299.38 to 340.35) K. Journal of Chemical \& Engineering Data, 53(12):2907-2909. [doi:10.1021/je800662m]

Yang, J., Dai, L., Wang, X., Chen, Y., 2011. Di-p-nitrobenzyl azodicarboxylate (DNAD): an alternative azo-reagent for the Mitsunobu reaction. Tetrahedron, 67(7):1456-1462. [doi:10.1016/j.tet.2010.12.036]

Yang, M.M., Schneller, S.W., Korba, B., 2005. 5'-homoneplanocin a inhibits hepatitis B and hepatitis C. Journal of Medicinal Chemistry, 48(15):5043-5046. [doi:10.1021/jm058200e]

Yin, X.Q., Li, W.K., Schneller, S.W., 2006. An efficient Mitsunobu coupling to adenine-derived carbocyclic nucleosides. Tetrahedron Letters, 47(52):9187-9189. [doi:10. 1016/j.tetlet.2006.10.126]

Zheng, Q.H., Wang, J.Q., Liu, X., Fei, X.S., Mock, B.H., Glick-Wilson, B.E., Sullivan, M.L., Raikwar, S.P., Gardner, T.A., Kao, C.H., et al., 2004. An improved total synthesis of PET HSV-tk gene reporter probe 9- $\left(4-\left[{ }^{18} \mathrm{~F}\right]\right.$ fluoro-3-hydroxymethylbutyl) guanine ([ $\left.\left.{ }^{18} \mathrm{~F}\right] \mathrm{FHBG}\right)$. Synthetic Communications, 34(4):689-704. [doi:10.1081/ SCC-120027717] 